\title{
ISOTOPIC FRACTIONATION OF OXYGEN AND CARBON IN LIME MORTAR UNDER NATURAL ENVIRONMENTAL CONDITIONS
}

\author{
MARK J Y VAN STRYDONCK, MICHEL DUPAS \\ Royal Institute of Cultural Heritage, Brussels, Belgium \\ and \\ EDWARD KEPPENS \\ Departments of Geochronology and of Applied Geology, \\ Vrije Universiteit, Brussels
}

\begin{abstract}
The rate of calcite formation and the isotopic fractionation in lime mortar during the process of mortar setting were examined. The diffusion rate of atmospheric $\mathrm{CO}_{2}$ in the sample is the rate-controlling step of the chemical reaction. A Rayleigh diffusion in the mortar causes an enrichment of ${ }^{13} \mathrm{C}$ and ${ }^{18} \mathrm{O}$ in the samples.
\end{abstract}

\section{INTRODUCTION}

For several years laboratories have tried to clarify the isotopic fractionation during mortar setting. Some experiments were made in a natural environment while others were under artificial conditions during laboratory tests (Ambers, 1987; Pachiaudi et al, 1986). As results from these tests were inconclusive, we took another approach to this problem.

\section{SAMPLE PREPARATION}

To minimize discrepancies between the absorption of $\mathrm{CO}_{2}$ on real and test mortars, we tried to copy natural conditions as much as possible. The composition of fresh mortar used by ancient builders differs in time and space (Van Strydonck \& Dupas, 1988), but is essentially a mixture of lime $\left(\mathrm{Ca}(\mathrm{OH})_{2}\right)$, water and sand and an aggregate (eg, reworked bricks, marble). Pure $\mathrm{SiO}_{2}$ sand was used to eliminate all influences from fossil carbon. No aggregate was added because it is not an essential element and would only disturb the homogeneity of the sample. There was ca $12.5 \%$ of quicklime in the samples.

Quicklime and sand were mixed dry before water was added. In contact with water $\mathrm{CaO}$ is transformed into $\mathrm{Ca}(\mathrm{OH})_{2}$, which yields an exothermic reaction noticeable when handling the sample. As in normal mortar preparation, excess water was added to make the slurry more manageable.

In construction, mortar is applied in layers between stones or bricks. Some walls are completely impermeable, so that even after several centuries, some lime may still be present (Sonninen, Erämetsa \& Jungers, 1985). Mortar may be considered as a compressed bulk volume that absorbs $\mathrm{CO}_{2}$ from its surface. By placing the test mortar in glass tubes, which were sealed at one end, atmospheric $\mathrm{CO}_{2}$ could enter the sample in one direction. Tubes of different lengths were filled to compare thin and thick mortar layers. The samples were placed outdoors in a relatively unpolluted and shady area, protected from the dominating Westerly wind and occasionally 
heavy rainfall. Three theoretically identical sets were made. Each set contained 6 tubes from $1-12 \mathrm{~cm}$ long. The 1st series was left outside for 12 months, the second series for 28 months and the third series for 33 months.

\section{CHEMICAL ANALYSES}

We should note that, although all samples were prepared in the same way, they were not identical. Despite our efforts to make a homogeneous mixture, we noticed differences in the gray color of the mortar. Supposedly, $\mathrm{CaO}$ particles tend to cluster together to various degrees upon the addition of water. Also in filling the tubes, we observed small tunnels in the mortar left by water evaporation caused by a rise in temperature from immediate $\mathrm{Ca}(\mathrm{OH})_{2}$ formation.

Except for minor differences, the three sets of samples are practically equal in weight. Apparently, each sample lost ca $10 \%$ of its original weight during the experiment, obviously through evaporation of excess water. This evaporation took place within the first 12 months. None of the samples was completely carbonated, because they still contained free $\mathrm{Ca}(\mathrm{OH})_{2}$.

The evolution of $\mathrm{CO}_{2}$ absorption is shown in Figure 1, indicating the total amount of $\mathrm{Ca}$, which has reacted to $\mathrm{CaCO}_{3}$. The point of absorption

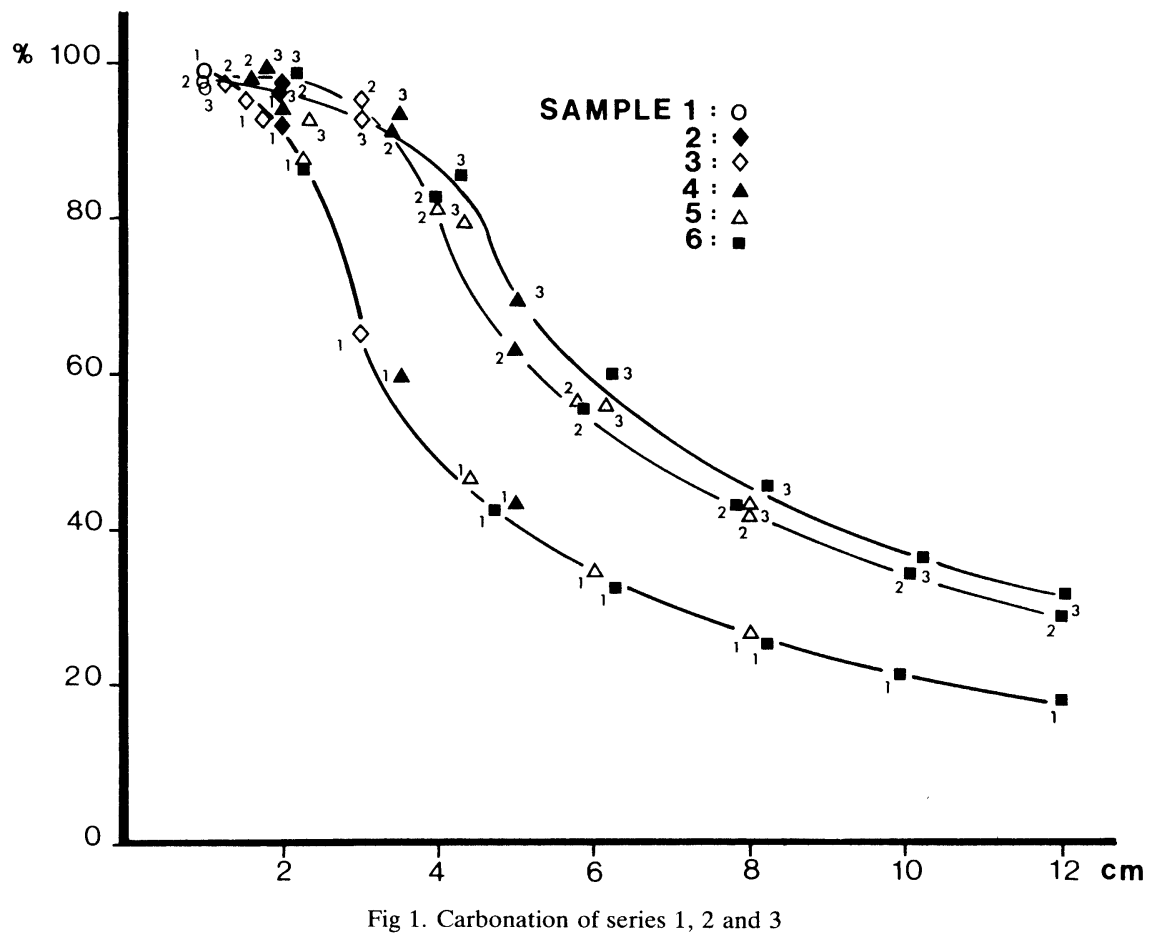

of $\mathrm{CO}_{2}$ starts at the surface and ends at the point indicated on the abscissa (1st, 2nd \& 3rd series). Figure 1 shows that the total height of the pillar has no influence on the carbonate content of a certain level. Only the 
amount of material between the surface and the sample has an influence. The right part of each curve can be described by a logarithmic function:

$$
\ln \mathrm{Y}=\mathrm{A} \cdot \mathrm{X}+\mathrm{B}
$$

\begin{tabular}{cccc}
\hline Series & A & B & $\begin{array}{c}\text { Correlation } \\
\text { coefficient }\end{array}$ \\
\hline 1st series & -0.147 & 4.472 & -0.982 \\
2nd series & -0.112 & 4.680 & -0.993 \\
3rd series & -0.101 & 4.662 & -0.981 \\
\hline
\end{tabular}

Thus, the absorption of $\mathrm{CO}_{2}$ can be described as a first-order reaction, during which reaction kinetics are controlled by the exhaustion of one of the reagents. Here, the exhaustion is not a function of time, but of depth. The rate-controlling step cannot be the chemical reaction itself. Since there is an excess of $\mathrm{Ca}(\mathrm{OH})_{2}$ in the system, the $\mathrm{pH}$ is maintained at ca 11. Consequently, all $\mathrm{CO}_{2}$ that goes into solution will precipitate immediately as $\mathrm{CaCO}_{3}$. The only parameter left is the diffusion rate, which will be a function of the partial pressure of $\mathrm{CO}_{2}$ in the atmosphere, the permeability of the mortar and the amount of $\mathrm{Ca}(\mathrm{OH})_{2}$ in the sample. Figure 1 shows an inflection at ca $65-70 \%$ of Ca converted into carbonate. This inflection indicates a change in reaction rate which can only be caused by a change in the diffusion of the $\mathrm{CO}_{2}$ through the pillar.

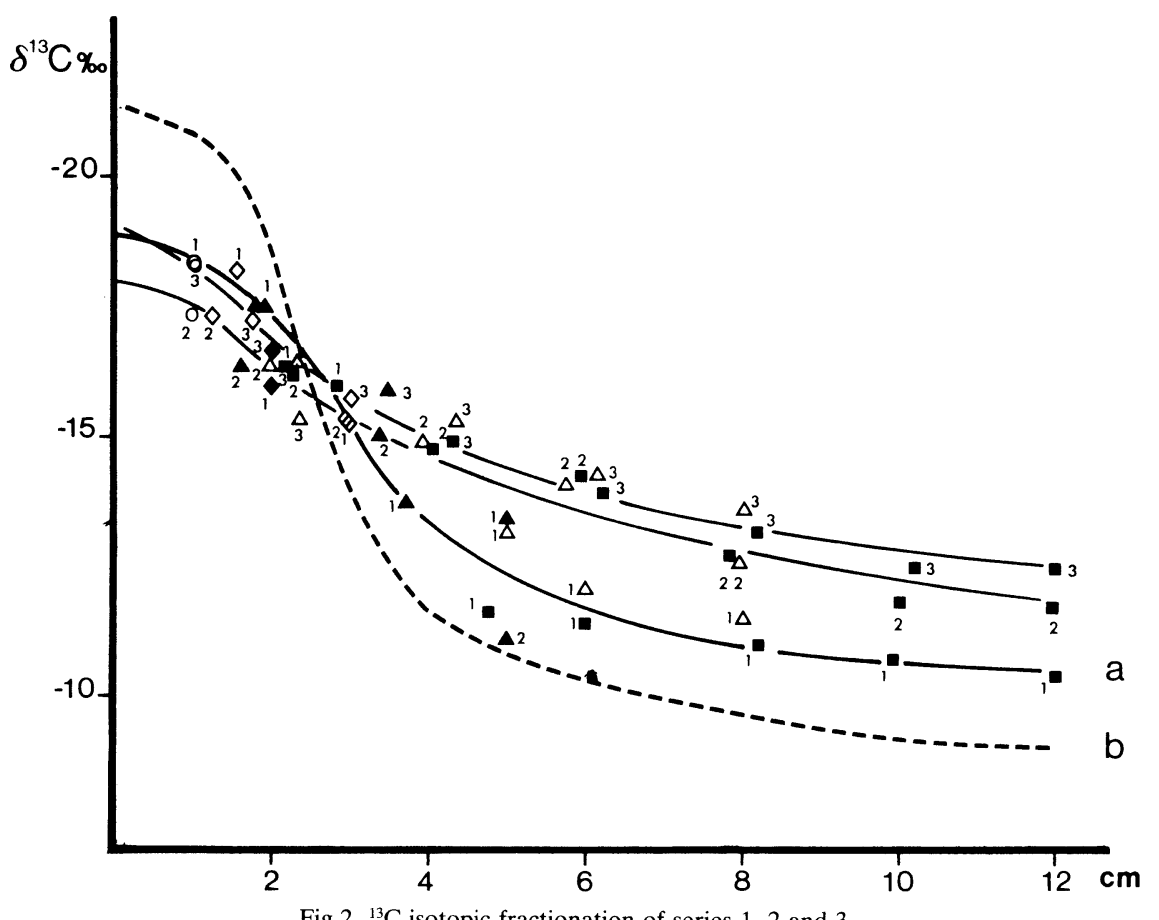

Fig $2 .{ }^{13} \mathrm{C}$ isotopic fractionation of series 1,2 and 3 
During the evolution of the reaction, the inflection point moves deeper in the pillar but stays at ca $65 \%$ conversion. It is obvious that this change is related to the degree of carbonation, probably caused by a compaction of the material (Lafuma, 1952).

\section{ISOTOPIC FRACTIONATION}

Carbon and oxygen isotope analyses were carried out on a FinniganMAT Delta E mass spectrometer. The analytical uncertainty on the isotope ratio measurements are ca $0.02 \%$ for $\delta^{13} \mathrm{C}$ and $0.03 \%$ for $\delta^{18} \mathrm{O}$. The overall analytical uncertainty (ie, external reproducibility) on these samples, however, is much larger, mainly because of their inhomogeneity, their extremely low carbonate content and the uncontrolled temperature rise caused by the reaction of $\mathrm{Ca}(\mathrm{OH})_{2}$ with phosphoric acid has a bearing on the isotopic fractionation, especially of oxygen. Based on five repeated analyses, the external reproducibility may be estimated at ca $1 \%$ for carbon and $2 \%$ for oxygen.

\section{Carbon Isotope Fractionation}

The results of stable carbon isotope analyses on the different levels are grouped in Table 1 and Figure 2. These results can only be discussed if

$$
\text { TABLE } 1
$$

Isotopic fractionation

\begin{tabular}{ccccccc}
\hline & \multicolumn{2}{c}{ 1st series } & \multicolumn{2}{c}{ 2nd series } & \multicolumn{2}{c}{$\cdots 3$ 3rd series } \\
\cline { 2 - 7 } No. & $\delta^{13} \mathrm{C}$ & $\delta^{18} \mathrm{O}$ & $\delta^{13} \mathrm{C}$ & $\delta^{18} \mathrm{O}$ & $\delta^{13} \mathrm{C}$ & $\delta^{18} \mathrm{O}$ \\
\hline 1 & -18.40 & -20.05 & -17.43 & -19.14 & -18.31 & -19.14 \\
\hline 2 & -16.95 & -21.31 & -15.98 & -21.07 & -16.57 & -21.07 \\
\hline 3a & -18.20 & -20.53 & -17.29 & -19.86 & -17.22 & -19.86 \\
3b & -12.10 & -23.27 & -14.02 & -22.31 & -13.36 & -22.31 \\
\hline 4a & -17.50 & -21.69 & -16.83 & -20.14 & -17.47 & -20.14 \\
4b & -8.98 & -22.10 & -13.99 & -22.56 & -14.26 & -22.56 \\
4c & -12.60 & -16.21 & -8.21 & -19.82 & -3.09 & -21.73 \\
\hline 5a & -16.45 & -21.26 & -16.38 & -20.72 & -15.39 & -20.72 \\
5b & -9.43 & -17.31 & -13.44 & -22.07 & -15.04 & -22.07 \\
5c & -9.10 & -21.11 & -12.57 & -14.39 & -11.71 & -17.75 \\
5d & -9.60 & -14.29 & -11.85 & -18.28 & -11.22 & -17.40 \\
\hline 6a & -16.05 & -22.23 & -16.16 & -20.67 & -16.29 & -20.19 \\
6b & -7.73 & -19.94 & -13.46 & -21.98 & -13.46 & -21.97 \\
6c & -10.70 & -15.92 & -12.90 & -15.76 & -11.72 & -15.72 \\
6d & -9.50 & -22.66 & -11.11 & -15.54 & -10.46 & -15.00 \\
6e & -9.35 & -22.23 & -10.52 & -14.52 & -9.77 & -15.12 \\
6f & -9.10 & -19.27 & -12.06 & -15.84 & -12.23 & -17.98 \\
\hline
\end{tabular}


there is an agreement on the expected fractionation resulting from the reaction of atmospheric $\mathrm{CO}_{2}$ with lime. Tests run on very small samples (Pachiaudi et al, 1986) showed a $\delta^{13} \mathrm{C}$ of $-21.7 \%$. This result is confirmed by $\delta^{13} \mathrm{C}$ measurements on scums and travertines that were directly related to waters with a pH of 11 or above (O'Neil \& Barnes, 1971). In the latter study, the mean of 6 measurements (not including 1 outlier) was indeed $-21.2 \pm 3.1 \%$. A diffusion fractionation at the interface air-liquid was considered to cause this fractionation (McCrea, 1950).

Letolle (1988) notes, however, that a wrong interpretation of older data leads to the wrong conclusion that this was an equilibrium value. The problem is that Pachiaudi noticed a constant isotopic fractionation during $\mathrm{CO}_{2}$ absorption on a lab scale test regardless of what was measured on real mortars. To avoid this, we could characterize the reaction by a fractionation factor (Fritz \& Fontes, 1980) $\alpha_{\mathrm{A}-\mathrm{B}}$ :

$$
\alpha_{\mathrm{A}-\mathrm{B}}=\frac{1000+\delta_{\mathrm{B}}}{1000+\delta_{\mathrm{A}}}
$$

Using Pachiaudi's values

$$
\delta_{\mathrm{A}}=-8.2 \% \text { and } \delta_{\mathrm{B}}=-21.7 \% \mathrm{o}
$$

the fractionation factor becomes: $\alpha=0.986$

and the isotopic separation factor $\left(\varepsilon_{\mathrm{A}-\mathrm{B}}\right)$ :

$$
\varepsilon_{\mathrm{A}-\mathrm{B}}=\left(\alpha_{\mathrm{A}-\mathrm{B}}-1\right) \times 1000=-13.61
$$

meaning that the carbonate is ca $1.4 \%$ depleted in ${ }^{13} \mathrm{C}$.

The depletion in ${ }^{13} \mathrm{C}$ downward in the mortar pillar can be explained only if a Rayleigh-type diffusion is assumed, a process related to a Rayleigh distillation (Fritz \& Fontes, 1980). This model describes a batch distillation where an equilibrium is supposed to exist between a gas phase and a liquid. If small quantities of the gas are continuously removed, a constant reequilibration will take place between the relative concentration of the products in the liquid and gas phases.

Assuming a closed system, the following balance equation is valid:

$$
\mathrm{f} \cdot \delta_{\mathrm{A}}+(1-\mathrm{f}) \cdot \delta_{\mathrm{B}}=\delta_{\mathrm{A}^{\circ}}
$$

where $\delta_{\mathrm{A}}$ and $\delta_{\mathrm{B}}$ are, respectively, the isotopic compositions of air and carbonate at a certain level in the pillar; $\delta_{\mathrm{A}^{\circ}}$ represents the initial composition of $\mathrm{CO}_{2}$ in the air $(-8 \%$ ) (Mook \& Waterbolk, 1985), and $\mathrm{f}$, the residual fraction of the reagent. Applying this model, we write:

$$
\mathrm{f} \cdot \delta_{\mathrm{A}}+(1-\mathrm{f}) \cdot \delta_{\mathrm{B}}=-8
$$

taking into account the isotopic separation factor:

$$
\mathrm{f} \cdot\left(\delta_{\mathrm{B}} / 2.65\right)+(1-\mathrm{f}) \cdot \delta_{\mathrm{B}}=-8 .
$$


Since carbonatization is instantaneous when $\mathrm{CO}_{2}$ comes in contact with the alkaline liquid phase, we can assume that the fraction of $\mathrm{CO}_{2}$ which has diffused through a certain level in the pillar and did not react, is equal to 1 minus the fraction of carbonate formed above that level.

$$
\text { If } \mathrm{F}=(\% \mathrm{Ca} \text { reacted }) / 100 \text {, then } \mathrm{f}=1-\mathrm{F} .
$$

Equation (5) then becomes

$$
(1-\mathrm{F}) \cdot\left(\delta_{\mathrm{B}} / 2.65\right)+\mathrm{F} \cdot \delta_{\mathrm{B}}=-8 .
$$

Figure 2 (b) illustrates this theoretical Rayleigh-diffusion for the first series.

However it must be noted that, at lower levels especially, the carbonate is more depleted in ${ }^{13} \mathrm{C}$ than can be explained theoretically. This is certainly not unexpected since the pillar is neither a closed nor an ideal system. There is a constant input of $\mathrm{CO}_{2}$ from the atmosphere which isotopically dilutes the remaining $\mathrm{CO}_{2}$, keeping it isotopically lighter than would be expected in a closed system. Also, the atmosphere is not an ideal gas, and the "lime pillars" are not ideal, homogeneous nor pure chemical mixtures. Some anomalies, as in sample 6 of the first series, might result from the presence of small channels, which means that level "a" had a better contact with the atmosphere than did level "c", yet, level "c" had much more contact than level "b."

\section{Oxygen Isotope Fractionation}

We can see that the $\delta^{18} \mathrm{O}$ behaves like the $\delta^{13} \mathrm{C}$ (Fig 3). Although both the water and the $\mathrm{CO}_{2}$ oxygen contribute to the solid carbonate experiments, O'Neil and Barnes (1971) have shown that on rapid precipitation of $\mathrm{CO}_{2}$ in an alkaline solution, $2 / 3$ of the oxygen in the solid carbonate comes directly from the $\mathrm{CO}_{2}$. Although the contribution of water is minor, it is responsible for the enrichment in ${ }^{18} \mathrm{O}$ in the near-surface layers. Due to the important evaporation of water (ca $10 \%$ of the sample weight) especially near the surface of the pillar, the remaining water will be enriched in ${ }^{18} \mathrm{O}$.

\section{COMPARISON WITH REAL MORTAR}

The isotopic fractionation curves obtained on the artificial mortar closely resemble the curves obtained during real mortar dating (Van Strydonck et al, 1983, 1986), when different fractions are taken (Fig 4). In a mixture of rock and carbonate mortar, the mortar, due to its morphology, tends to react more easily with an acid solution than the carbonate rock (Folk \& Valastro, 1976, 1979). This results in a somewhat younger ${ }^{14} \mathrm{C}$ age of the $\mathrm{CO}_{2}$ at the beginning of the acid reaction. The slope of this line indicates the presence of fossil carbonate. The linear relationship of the ${ }^{14} \mathrm{C} /{ }^{12} \mathrm{C}$ ratios between the fractions should impose a linear relationship between the ${ }^{13} \mathrm{C} /{ }^{12} \mathrm{C}$ ratios. The results, however, show a supplementary fractionation provoked by a Rayleigh diffusion on the semi-micro scale of the ground mortar $(0.25 \mathrm{~mm}$ grain size $)$. 


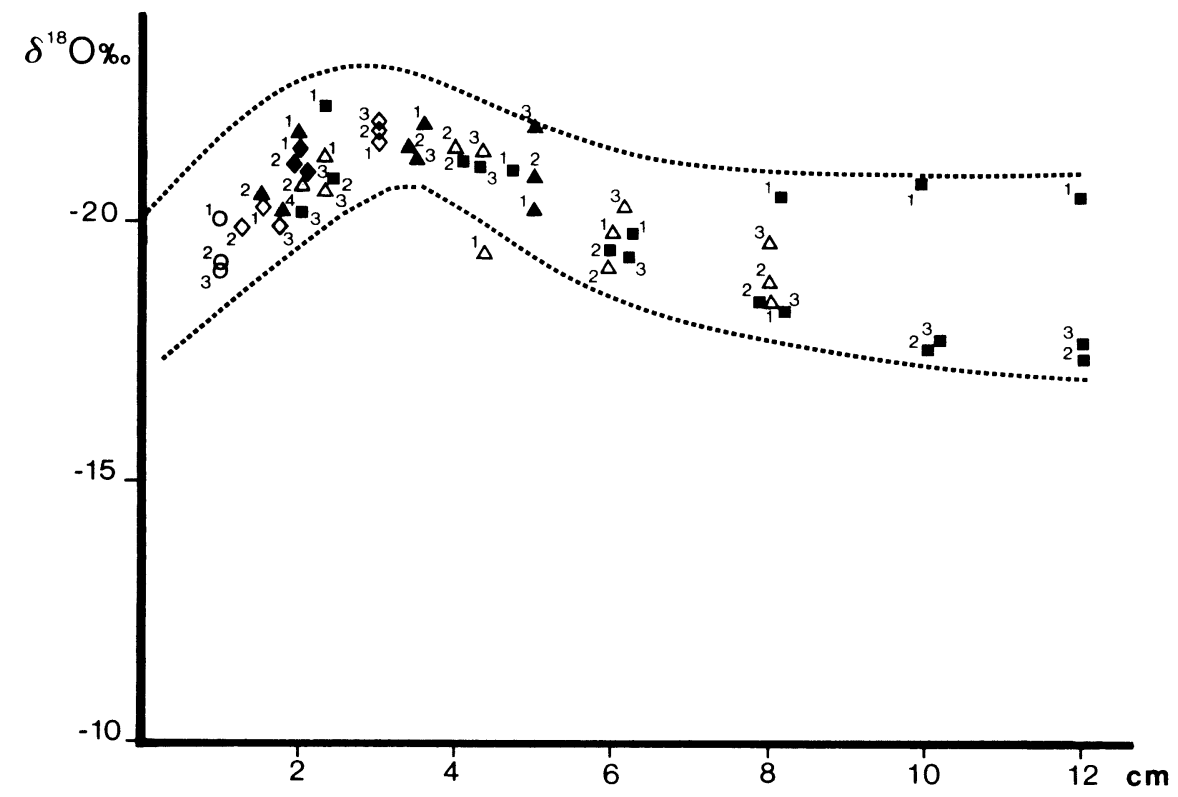

Fig $3 .{ }^{18} \mathrm{O}$ isotopic fractionation of series 1,2 and 3

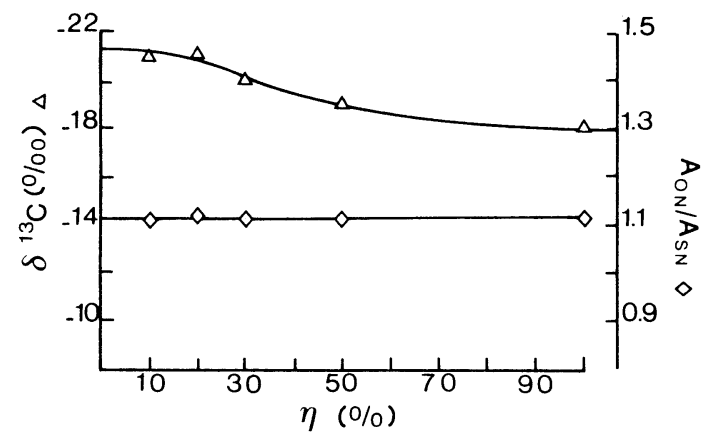

Fig 4. Mortar from Heilige-Kruis Church at Vrasene (Belgium). Very pure sample from lime slaking, hardly any trace of fossil carbonate present. ${ }^{14} \mathrm{C}$ dating confirmed that the sample came from 12th and not 14 th century construction. 
It is possible that after carbonatization, the mortar equilibrates with the atmosphere, but the diffusion rate is then so low that in most cases (7 out of 8) (Van Strydonck et al, 1986) the mortar becomes isolated from the atmosphere.

\section{CONCLUSIONS}

We have tried to demonstrate that neither $\delta^{13} \mathrm{C}$ nor $\delta^{18} \mathrm{O}$ can provide any information on the fossil carbonates in mortar; this can only be derived from the ${ }^{14} \mathrm{C}$ content of each fraction. Isotopic fractionation, however, does provide data on the reaction mechanism and more specifically, on the $\mathrm{CO}_{2}$ diffusion model. Thus, it might indirectly contribute to our knowledge of the manufacture of mortar (compaction, structure) and its use in wall construction (permeability).

However, we would like to emphasize that our model is valid only for the normal type of lime mortars. In the case of pure lime, without sand or aggregate, there seems to be a relationship between the amount of Ca transformed into carbonate and isotopic fractionation. We have measured depletion and not enrichment, in ${ }^{13} \mathrm{C}$ during absorption (Pachiaudi et al, 1986; Van Strydonck \& Dupas, 1988; Van Strydonck \& Waldren, 1.987). This work, however, is still in progress.

\section{ACKNOWLEDGMENTS}

The authors wish to thank Mr and Mrs Van Strydonck-Vereecke for keeping the samples on their property for 33 months and A Van Maele for technical assistance. Preliminary stable isotope work on some of the samples was carried out in collaboration with $\mathrm{J} R$ O'Neil at the U S Geological Survey, Menlo Park, California.

\section{REFERENCES}

Ambers, J, 1987, Stable carbon isotope ratios and their relevance to the determination of accurate dates for lime mortars: Jour Archeol Sci, v 14, p 569-576.

Folk, R L and Valastro, S, 1976, Successful technique for dating of lime mortar by carbon-14: Jour Field Archaeol, v 3, p 203-208.

1979, Dating of lime by ${ }^{14} \mathrm{C}$, in Berger, $\mathrm{R}$ and Suess, H E eds, Radiocarbon dating, Internatl ${ }^{14} \mathrm{C}$ conf, 9th, Proc: Berkeley, Univ California Press, p 721-732.

Fritz, P and Fontes, J C, 1980, The terrestrial environment, in Handbook of environmental isotope geochemistry: Amsterdam, Elsevier, $532 \mathrm{p}$.

Lafuma, H, 1952, Liants hydrauliques. Propriétés, choix et condiditions d'emploi: Paris, Editions Dunod, 128 p.

Letolle, R, 1988, Letter to the editor: Radiocarbon, v 30, no. 1, p 129.

McCrea, J M, 1950, On the isotopic chemistry of carbonates and a paleotemperature scale: Jour Chem Physics, v 18, p 849-857.

Mook, W G and Waterbolk, H T, 1985, Radiocarbon dating, in Handbooks for archaeologists, No. 4: Strasbourg, Editions European Sci Found, 65 p.

O'Neil, J and Barnes, I, $1971,{ }^{13} \mathrm{C}$ and ${ }^{18} \mathrm{O}$ compositions in some fresh-water carbonates associated with ultramafic rocks and serpentinites: western United States: Geochim et Cosmochim Acta, v 35, p 687-697. 
Pachiaudi, C, Maréchal, J, Van Strydonck, M, Dupas, M and Dauchot-Dehon, M, 1986, Isotopic fractionation of carbon during $\mathrm{CO}_{2}$ absorption by mortar in Stuiver, $\mathrm{M}$ and Kra, R S, eds, Internatl ${ }^{14} \mathrm{C}$ conf, 12th, Proc: Radiocarbon, v 28, no. 2A, p 691-697.

Sonninen, E, Erämetsä, P and Jungner, H, 1985, Dating mortar and bricks from the castle of Kastelholm: Iskos, v 5, p 384-389.

Van Strydonck, M J Y and Dupas, M, in press, The classification and dating of lime mortars by chemical analyses and radiocarbon dating: A review, in The Deya conference of prehistory, 2nd: Mallorca.

Van Strydonck, M, Dupas, M, Dauchot-Dehon, M, Pachiaudi, C and Maréchal, J, 1983, A further step in the radiocarbon dating of old mortars: Bull Kon Inst Kunstpatrimonium, v XIX, 1982/83, p 155-171.

1986, The influence of contaminating (fossil) carbonate and the variations of ${ }^{13} \mathrm{C}$ in mortar dating in Stuiver, $\mathrm{M}$ and $\mathrm{Kra}, \mathrm{R} \mathrm{S}$, eds, Internatl ${ }^{14} \mathrm{C}$ conf, 12th, Proc: Radiocarbon, $v 28$, no. $2 \mathrm{~A}$, p 702-710.

Van Strydonck, M J Y and Waldren, W H, in press, Radiocarbon dating of Mallorcan lime burials, in Internatl symposium, Archaeology and ${ }^{14} \mathrm{C}$, 2nd, Proc: PACT. 